\title{
住宅小区园林绿化施工与环保理念的管理
}

\author{
阮一均 周仙朵 \\ 浙江中煌建设有限公司
}

DOI:10.32629/btr.v3i3.2925

[摘 要] 如何在小区绿化中提高绿化质量,提升绿化品位,积极探索在城市小区绿化中遵循崇尚自然、高于自然的造景式园林绿化的施工管理, 现就小区园林绿化施工管理进行阐述。

[关键词] 小区; 园林绿化; 施工

\section{1 对施工图纸认真解析,对工程进行质量控制}

住宅区中标后, 建设单位必须首先与建设单位合作, 对绿化准备场 地进行勘测, 并要求建设单位认真阅读和理解设计图纸, 了解设计意图 和内容。图纸的概念, 并明确设计目的和技术要求。景观要素和景观核 心区域必须结构完善且成熟。同时, 组织邀请设计单位和施工单位的工 程技术人员举行图纸审查会议, 并完成会议记录。在会议上,讨论检查图 纸时是否存在设计缺陷, 是否与要准备的绿色区域相符, 是否可以与绿 色区域的特征相结合以及它们是否会影响图纸的质量。施工。对设计单 位的反馈, 要求设计单位进行设计更改。一般来说, 设计图与设计图之后 的可操作性略有差异。只有当设计图纸易于构造并符合规格要求时, 才 能保证施工质量。

\section{2 小区园林绿化施工现场管理}

2. 1 定点线的处理

为了严格按照施工图的要求进行定点线铺设, 在施工现场应清楚标明 种植槽线和种植孔的中心, 标记必须清晰准确。在铺设过程中遇到路灯柱 等障碍物时, 应适当调整植株之间的距离, 以确保植株与灯柱之间的距离 不小于 $2.0 \mathrm{~m}$, 且高大乔木应保持在 3.0 以上米距离。当场地条件与设计图不 符时, 房地产单位负责人应当咨询社区绿化工程管理负责人, 图设计师和 监理, 将施工结果告知建设单位, 取得许可证后作出相应调整。

2.2场地清理和整平工作

在进行绿化工程之前, 必须清理施工现场, 清理场地中的建筑废料, 废 料和杂草, 并根据图纸和 “花园绿化施工标准” 对场地进行回填和找平。平 整过程应根据现场的自然情况进行操作, 尽量保持现有的自然环境, 保持 趋势顺畅, 错开高度, 避免人工找平破坏自然形态。在回填过程中, 应根据 各种植物特征掌握土壤覆盖层的厚度。通常, 树木, 灌木和草皮的土壤最小 厚度分别为 80 厘米, 50 厘米和 30 厘米。

\section{3做好土壤处理}

为了确保各种植物都能保持良好的生长状况, 在施工前应对该地区 的土壤进行化学测试, 并掌握诸如 $\mathrm{pH}$, 透水性和透气性等土壤指标。根据 这些指标, 有针对性地施肥, 置换土壤, 排水, 通风和其他促进土壤生长 的手段。

2. 4 种植苗木和草坪

固定线铺设工作完成后, 应事先进行种植坑的开挖工作。通常, 短花灌 木的种植大多是行孔。圆形的种植孔适合种植高大的乔木和灌木。完成这
项工作后, 应根据规格更换土壤, 然后种植幼苗。

(1) 凉亭建设。移植树木之前, 我们必须首先了解天气状况, 并且必须 确保树木迁移, 运输和种植的三个环节的连续性。在夏初的施工过程中, 应尽量选择阴天, 阴雨天气种植, 并在晴天进行防晒。移植前 3 天应适当修 剪乔木, 以确保在蒸发过程中和种植后减少体内水分。种植前, 在造林孔中 回填 $20 \mathrm{~cm} \sim 35 \mathrm{~cm}$ 干净的好土壤, 施用适量的有机肥, 然后刮下地基。将树放 入种植孔中, 尽量不要解开绳索, 并在拉直后将其掩埋。在此过程中, 您必 须随时对其进行调整以确保树的姿势是直立的。倒入根水时, 必须确保水 量充足。种植完成后, 需要对高大的树木进行支撑和绑扎, 以确保树根的稳 定性和完整性。种植结束后, 应及时疏伐落叶树种, 以减少蒸腾作用, 提高 成活率。

(2) 建设开花灌木。将幼苗运输到施工现场后, 应立即种植。对于单独 种植的树木, 应确保树木的树冠。种植后还需要支撑大型植物的花灌木。

2.5加强施工后的维护管理

俗话说 “三点种植, 七点管理”, 特别是社区绿化建设, 要更加注意后 期的维护和管理, 以提高成活率。夏季要注意灌溉和喷雾维护, 必要时增加 棚的阴影。在严冬期间, 要进行耕种和包扎树干的工作。特别是要结合社 区和行人的复杂环境, 在施工结束后及时采取隔离和保护措施, 插入防护 性宣传标志, 警告附近居民踩踏, 挖掘, 破坏等不文明行为, 并防止农药, 电 源等有害事故。生存和保存期届满后, 应及时进行保存期, 并保持链接的连 续性, 并逐层实施细节。根据各种植物的生理特性, 应及时施肥, 修剪, 除草 和除草。御治, 防止病虫害的发生和传播。

\section{3 结束语}

近年来, 人们的生活质量越来越高, 城市建设的大规模发展导致城市 空气污染指数越来越高。人们越来越渴望新鲜空气, 他们对居住环境的质 量要求也越来越高。为了满足居民的需求, 有必要改善美化环境的质量和 品味。

\section{[参考文献]}

[1]刘志刚.住宅小区园林绿化施工技术分析 [J].工程建设与设 计,2018,(18):155-156.

[2]黄李光. 住宅小区园林绿化工程栽植施工技术分析一以温州市龙湾 城市中心区C -14地块景观技术工程为例[J].中国园艺文摘,2017,33(12):98-99.

[3] 薛长宝.住宅小区园林绿化工程的施工技术 [J].四川建 材,2017,43(08):155-156. 